\title{
Physiological and Molecular Characterization of Cephaleuros virescens Occurring in Mango Trees
}

\author{
Camila Vilela Vasconcelos ${ }^{1}$, Fabíola Teodoro Pereira ${ }^{1}$, Elizabeth Amélia Alves Duarte ${ }^{2}$, \\ Thiago Alves Santos de Oliveira ${ }^{3}$, Nei Peixoto ${ }^{1}$, and Daniel Diego Costa Carvalho ${ }^{1 *}$ \\ ${ }^{1}$ Universidade Estadual de Goiás, Rodovia GO 330, km 241, Anel Viário, Setor Universitário, 75.780-000, Ipameri, \\ Goiás, Brasil \\ ${ }^{2}$ Universidade Federal do Recôncavo da Bahia, Rua Rui Barbosa 710, Centro, 44.380-000, Cruz das Almas, Bahia, Brazil \\ ${ }^{3}$ Faculdade Maria Milza, Rodovia BR 101, Km 215, 44.350-000, Governador Mangabeira, Bahia, Brazil
}

(Received on September 1, 2017; Revised on January 30, 2018; Accepted on February 12, 2018)

The objective of this work was to accomplish the isolation, molecular identification and characterizing the physiology of the causal agent of the algal spot in mango trees. For this purpose, the pathogen growth was assessed in different culture media, with subsequent observation and measurements of the filamentous cells. The molecular identification was made using mycelium obtained from leaf lesions and pure algae colonies grown in culture medium. Descriptions based on DNA sequencing indicated that the algae is Cephaleuros virescens. The algae must be isolated primarily in liquid medium for further pricking into agar medium. The highest mycelial growth average in Petri dishes occurred when the algae were grown in Trebouxia and BBM. Trebouxia enabled larger cells in the filamentous cells when compared to other culture media.

Keywords : algal spot disease, algal isolation, Mangifera indica

Handling Associate Editor : Shim, Won Bo

Plant parasitic green algae comprise a separate group in the case of phytopathogenic agents. Insufficiently studied

\footnotetext{
*Corresponding author.

Phone) +55-64-3491-1556, FAX) +55-64-3491-1556

E-mail) daniel.carvalho@ueg.br

(c) This is an Open Access article distributed under the terms of the Creative Commons Attribution Non-Commercial License (http:// creativecommons.org/licenses/by-nc/4.0) which permits unrestricted noncommercial use, distribution, and reproduction in any medium, provided the original work is properly cited.
}

Articles can be freely viewed online at www.ppjonline.org. in Brazil, Cephaleuros virescens Kunze and C. parasiticus Karst as the main algal species (Agrios, 2005). The microorganism Cephaleuros sp. is a green alga of the Archaeplastida Kingdom, Chlorophyta Phylum, Ulvophyceae Class, Trentepohliales Order, and Trentepohliaceae Family, that parasitizes various host plants causing the disease known as algal leaf spot. The disease occurs in all tropical and subtropical regions of the world, between latitudes $32^{\circ} \mathrm{N}$ and $32^{\circ} \mathrm{S}$ (Malagi et al., 2011; Suto and Ohtani, 2009), where the temperature and humidity are suitable for their growth and reproduction (Nelson, 2008). Some economically important crops attacked by green algae include avocado, tea, coffee, cocoa, pepper, citrus, cashew and mango (Agrios, 2005; Malagi et al., 2011). The symptoms are circular orange spots with felt-like texture, that as time passes tend to expand, exhibiting smooth-surfaced and grayish-brown color, occupying large leaf extents (Han et al., 2011; Ponmurugan et al., 2009). Consequently, the damage arises from the reduction in the leaf photosynthetic area (Ponmurugan et al., 2007).

There are some limiting factors regarding the study of plant parasitic algae, such as growth in vitro, especially because many media do not contain the nutrients required by these organisms (Ponmurugan et al., 2010). The medium Potato Sucrose Agar (PSA), widely used for cultivation of various organisms, does not promote algae growth (Malagi et al., 2011). In contrast, synthetic media such as Trebouxia and Bristol have proved effective for algae growth (Ponmurugan et al., 2010).

In studies on the Cephaleuros characterization, molecular tools have helped identification by sequencing of conserved genes (Leliaert et al., 2012), although there are few sequences pertaining to this genus in databases. Therefore, 
the objective of this study was to carry out the molecular identification and to evaluate techniques and media for isolating and characterizing the physiology of Cephaleuros from mango (Mangifera indica L.) in different culture media.

\section{Materials and Methods}

Isolation in agar and liquid media. 'Amrapali' mango leaves showing algae spots were collected from 8-year-old trees, from an orchard located within Goiás State University (UEG), Ipameri Campus, Goiás, Brazil (17\%43'00.38'S, $\left.48^{\circ} 08^{\prime} 40.96^{\prime \prime} \mathrm{W}, 796 \mathrm{~m}\right)$. Small fragments $(5 \times 5 \mathrm{~mm})$ comprising the transition area between the injured tissue and healthy tissue were excised and then disinfected in a series, as follows: $70 \%$ alcohol $(30 \mathrm{~s}), 1 \%$ sodium hypochlorite $(30 \mathrm{~s})$ and SDW $(3 \times 60 \mathrm{~s})$. The disinfected (D) and nondisinfected (ND) fragments were sown in Petri dishes (1 fragment dish ${ }^{-1}$ ) containing culture media: (a) Potato Dextrose Agar (PDA; containing g l $^{-1}: 200 \mathrm{~g}$ potato, $20 \mathrm{~g}$ dextrose, $20 \mathrm{~g}$ agar); (b) Potato Sucrose Agar (PSA, containing $\mathrm{g} \mathrm{l}^{-1}: 200 \mathrm{~g}$ potato, sucrose $20 \mathrm{~g}$, agar $20 \mathrm{~g}$ ); (c) Bold Basic Medium [BBM; containing $\mathrm{g} \mathrm{l}^{-1}$ : (1) $25 \mathrm{~g} \mathrm{NaNO}_{3}$, (2) $2.5 \mathrm{~g}$ $\mathrm{CaCl}_{2} \cdot 2 \mathrm{H}_{2} \mathrm{O}$, (3) $7.5 \mathrm{~g} \mathrm{MgSO}_{4} \cdot 7 \mathrm{H}_{2} \mathrm{O}$, (4) $7.5 \mathrm{~g} \mathrm{~K}_{2} \mathrm{HPO}_{4}$, (5) $17.5 \mathrm{~g} \mathrm{KH}_{2} \mathrm{PO}_{4}$ (6) $2.5 \mathrm{~g} \mathrm{NaCl}$, (7) $50.0 \mathrm{~g}$ EDTA (8) 31.0 g KOH (9) $4.98 \mathrm{~g} \mathrm{FeSO}_{4} \cdot 7 \mathrm{H}_{2} \mathrm{O}$, (10) $11.42 \mathrm{~g} \mathrm{H}_{3} \mathrm{BO}_{3}$, (11) $1 \mathrm{ml} \mathrm{H}_{2} \mathrm{SO}_{4}$ (12) micronutrient solution containing $\mathrm{g}^{-1}$ : $8.82 \mathrm{~g} \mathrm{ZnSO}_{4} \cdot 7 \mathrm{H}_{2} \mathrm{O}, 1.44 \mathrm{~g} \mathrm{MnCl}_{2} \cdot 4 \mathrm{H}_{2} \mathrm{O}, 0.71 \mathrm{~g} \mathrm{MoO}_{3}$, $1.57 \mathrm{~g} \mathrm{CuSO}_{4} \cdot 5 \mathrm{H}_{2} \mathrm{O}, 0.49 \mathrm{~g} \mathrm{Co}\left(\mathrm{NO}_{3}\right)_{2.6} \mathrm{H}_{2} \mathrm{O}$; prepared with $10 \mathrm{ml}$ of solutions 1-6, $940 \mathrm{ml}$ of SDW, $1 \mathrm{ml}$ of solutions 7-12 and 22 g agar]; (d) agarized host leaf extract (HLE; containing 11 of filtrate from $100 \mathrm{~g}$ of the crushed healthy mango leaves, $20 \mathrm{~g}$ sucrose, $20 \mathrm{~g}$ agar); (e) Bristol (containing $\mathrm{g} \mathrm{l}^{-1}: 0.097 \mathrm{~g} \mathrm{FeCl}_{2}, 0.004 \mathrm{~g} \mathrm{MnCl}_{2}, 0.005 \mathrm{~g} \mathrm{ZnCl}_{2}, 0.002$ $\mathrm{g} \mathrm{CaCl}_{2}$, and $0.004 \mathrm{~g} \mathrm{Na}_{2} \mathrm{MoO}_{4}$ and $20 \mathrm{~g}$ agar) (Ponmurugan et al., 2010); and (f) Trebouxia ( $\mathrm{g} \mathrm{l}^{-1}$ : containing $10 \mathrm{~g}$ proteose peptone, $20 \mathrm{~g}$ glucose, $60 \mathrm{ml}$ Bristol solution and 20 $\mathrm{g}$ agar). All the above-mentioned growth media were autoclaved at $121^{\circ} \mathrm{C}$ for $15 \mathrm{~min}$. After 7 days at $25^{\circ} \mathrm{C}$ and $12 \mathrm{~h}$ photoperiod, the growth assessment was performed.

For isolation in liquid media, small fragments (D and ND) were transferred to liquid media: PD, PS, BBM, HLE, Bristol and Trebouxia. After inoculation in liquid media ( 5 fragments Erlenmeyer ${ }^{-1}$ ), the flasks were put into the shaker at $120 \mathrm{rpm}$ at $25^{\circ} \mathrm{C}$ and $12 \mathrm{~h}$ photoperiod for 3 days. Then growth evaluation was carried out according to the previous description. After isolation, algal mycelium fragments were transferred from the Trebouxia liquid medium to agar media: PDA, PSA, BBM, HLE, Bristol and Trebouxia. This procedure allowed the obtaining of the $C$. virescens isolate $\mathrm{H}-27-01$ (obtained from agar BBM).

The assessement comprise of measuring the diameter $(\mathrm{cm})$ of the colonies grown on agaric medium and measuring the mycelium volume $(\mathrm{ml})$ of colonies grown on liquid media. The values obtained were converted to percentage in relation to the total area (agaric media) and to the total volume (liquid media).

Molecular characterization. The vegetative and reproductive algal tissue obtained from mango injured leaves and $\mathrm{H}$ 27-01 mycelium were used for DNA extraction using UltraClean ${ }^{\circledR}$ Microbial DNA Isolation kit (Mobio, Germantown, MD, USA), following the manufacturer's recommendations. The DNA integrity and quantity was verified by using agarose gel electrophoresis at $0.8 \%$ and Qubit $^{\circledR}$ 2.0 Fluorometer (Invitrogen, Carlsbad, CA, USA), respectively. PCR amplifications were performed with universal primers of the rRNA 18S nuclear gene (Hamby et al., 1988), designated as $18 \mathrm{SHf}$ and 18SLr, using the following reagents and concentrations: 60 ng DNA from each sample; 1x Taq DNA polymerase enzyme buffer; $3.7 \mathrm{mM}$

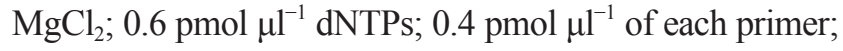
$5 \mathrm{U}$ Taq DNA polymerase, adjusted to a final volume of 50 $\mu l$ with ultrapure water. The amplification cycles were performed in a Veriti Thermal Cycler PCR (Applied Biosystems, Waltham, MA, USA) at initial denaturation temperature of $95^{\circ} \mathrm{C}$ for $3 \mathrm{~min} ; 30$ amplification cycles at $95^{\circ} \mathrm{C}$ for $1 \mathrm{~min} ; 52^{\circ} \mathrm{C}$ for $1 \mathrm{~min} ; 72^{\circ} \mathrm{C}$ for $2 \mathrm{~min}$, and final extension at $72^{\circ} \mathrm{C}$ for $10 \mathrm{~min}$. The amplified products were visualized in agarose gel at $1 \%\left(\mathrm{wt} \mathrm{vol}^{-1}\right)$, stained with $\mathrm{EtBr}$ and visualized under UV light. Then, the amplicons were purified using the PureLink ${ }^{\mathrm{TM}}$ PCR Purification kit (Invitrogen) for subsequent nucleotide identification using the automatic sequencer ABI-PRISM 310 Genetic Analyzer (Applied Biosystems). The editing and assembling of sequences were performed with the Sequencher 4.1.4 software (Gene Code Corporation, Ann Arbor, MI, USA). The taxonomic identity of the isolates was verified through the GenBank database, using the Basic Local Alignment Search Tool (BLAST) of NCBI (http://www.ncbi.nlm.nih.gov).

Mycelial growth. Agar discs containing the mycelium from the H-27-01 isolate were pricked into BBM, HLE, Bristol and Trebouxia, amounting to 10 Petri dishes for each culture medium. After 4 days at $25^{\circ} \mathrm{C}$ and $12 \mathrm{~h}$ photoperiod, the colony diameters were measured. At 15 days, algal mycelium were removed for slide making, using sterile distilled water as mounting means, where it was possible to measure the filamentous cells ( 40 cells). In another experiment, aimed at inducing gametangium-like bodies 
production from filamentous cells by hormone addition, the H-27-01 isolate was again picked for BBM, HLE, Bristol and Trebouxia, wherein for each culture medium, 20 Petri dishes were poured: 10 dishes included indole-3-acetic acid added (IAA) and 10 dishes added of gibberellic acid $\left(\mathrm{GA}_{3}\right)$, both at $150 \mathrm{mg} \mathrm{l}^{-1}$. After 15 days, algal mycelia were removed to observe gametangium-like body production.

Statistical analysis. The results for colony growth in agar medium (at four days) were subjected to regression analysis. The filamentous cells measurement results were subjected to the Scott-Knott test $(P \leq 0.05)$ with the help of SISVAR 5.3 software (UFLA, Lavras, Brazil) (Ferreira, 2011).

\section{Results}

Isolation in agar and liquid media. After isolation of algae on to solid media, no culture medium resulted in $C$. virescens development (Table 1). Among the analyzed liquid media, PD, PS, BBM, HLE and Bristol did not promote in vitro algae growth, for either $\mathrm{D}$ or ND plant tissue.
However, Trebouxia liquid medium enabled alga isolation (D and ND), where there was an increase of $24 \%$ and $8 \%$ of the culture medium volume, respectively (Table 1). After success with liquid media, algal fragments cultivated in Trebouxia were transferred to agar BBM to obtain the $\mathrm{H}-27-01$ isolate. After purification, the H-27-01 isolate was cultivated in solid media (HLE, BBM, Bristol and Trebouxia), colonizing $70-80 \%$ of the Petri dish surface (Table 1).

Molecular characterization. Two sequences were obtained, of 527 and 682 base pairs, from DNA extracted from mycelia extracted from lesions of diseased leaves) and DNA from H-27-01 isolate mycelia. After alignment with sequences from GenBank (access numbers: AY052564.1; KM020142.1; KM020143.1; KM020147.1; KM020145.1; DQ399595.1 and DQ399594.1), the greatest similarity coefficients (96-94\%) were found for $C$. virescens.

Mycelial growth. The highest mycelial growth average in Petri dishes occurred when the algae were grown in Trebouxia and BBM media $(8.2$ to $8.0 \mathrm{~cm})$, higher than

Table 1. Selection of culture media for isolation and cultivation of Cephaleuros virescens from 'Amrapali' mango tree leaves. Ipameri, Goiás, Brazil

\begin{tabular}{|c|c|c|c|c|c|}
\hline \multirow{3}{*}{ Culture media } & \multicolumn{5}{|c|}{ Growth of Cephaleuros virescens ${ }^{\dagger}$} \\
\hline & \multicolumn{2}{|c|}{$\begin{array}{c}\text { Agar medium from fragments } \\
\text { of injured tissue }\end{array}$} & \multicolumn{2}{|c|}{$\begin{array}{c}\text { Liquid medium from fragments } \\
\text { of injured tissue }\end{array}$} & \multirow{2}{*}{$\begin{array}{c}\text { Agar medium from mycelium } \\
\text { obtained in Trebouxia } \\
\text { liquid medium }\end{array}$} \\
\hline & (D) & (ND) & (D) & (ND) & \\
\hline PDA & 0 & 0 & 0 & 0 & 0 \\
\hline PSA & 0 & 0 & 0 & 0 & 0 \\
\hline $\mathrm{BBM}$ & 0 & 0 & 0 & 0 & $80 \%$ \\
\hline HLE & 0 & 0 & 0 & 0 & $70 \%$ \\
\hline Bristol & 0 & 0 & 0 & 0 & $70 \%$ \\
\hline Trebouxia & 0 & 0 & $24 \%$ & $8 \%$ & $80 \%$ \\
\hline
\end{tabular}

"Percentage of surface area (agaric medium) or volume (liquid medium) of culture medium colonized by $C$. virescens colonies, ${ }^{\dagger}$ Evaluations of agar and liquid media from fragments of injured tissues at cultivation days 7 and 3, respectively, ${ }^{\S}$ Evaluations in agar media from mycelium obtained in Trebouxia liquid medium were carried out at cultivation day 4, (D) Fragment of disinfested plant tissue, (ND) Fragment of nondisinfested plant tissue.

Table 2. Growth of Cephaleuros virescens at evaluation day 4 and linear regression models. Ipameri, Goiás, Brazil

\begin{tabular}{ccccc}
\hline Culture media & Growth at day $4(\mathrm{~cm})^{\dagger}$ & Models & $\mathrm{R}^{2}(\%)$ & $(P \leq \mathrm{X})$ \\
\hline BBM & $8.0 \mathrm{a}$ & $\mathrm{y}=2.2210 \mathrm{x}-0.9900$ & 99.81 & 9.01 \\
HLE & $5.5 \mathrm{c}$ & $\mathrm{y}=1.4201 \mathrm{x}-0.0005$ & 0.05 \\
Bristol & $6.0 \mathrm{~b}$ & $\mathrm{y}=1.6195 \mathrm{x}-0.4450$ & 99.85 & 0.01 \\
Trebouxia & $8.2 \mathrm{a}$ & $\mathrm{y}=2.5015 \mathrm{x}-2.1325$ & 98.05 & 0.01 \\
Coefficient of variation $(\%)$ & 6.71 & & \\
\hline
\end{tabular}

Values followed by the same letter in column do not differ statistically by Scott-Knott test $(P \leq 0.05)$. 
Table 3. Dimensions of length and width of filamentous cells of Cephaleuros virescens cultivated in different media. Ipameri, Goiás, Brazil

\begin{tabular}{|c|c|c|}
\hline \multirow{2}{*}{ Culture media } & \multicolumn{2}{|c|}{ Cell dimensions ${ }^{\dagger}$} \\
\hline & Length $(\mu \mathrm{m})$ & Width $(\mu \mathrm{m})$ \\
\hline $\mathrm{BBM}$ & $46.4 \mathrm{~b}$ & $4.8 \mathrm{~b}$ \\
\hline HLE & $42.6 \mathrm{c}$ & $4.5 \mathrm{~b}$ \\
\hline Bristol & $39.1 \mathrm{c}$ & $4.8 \mathrm{~b}$ \\
\hline Trebouxia & $69.1 \mathrm{a}$ & $6.1 \mathrm{a}$ \\
\hline $\begin{array}{l}\text { Coefficient of } \\
\text { variation (\%) }\end{array}$ & 17.50 & 15.00 \\
\hline
\end{tabular}

Values followed by the same letter in column do not differ statistically by Scott-Knott test $(P \leq 0.05)$.

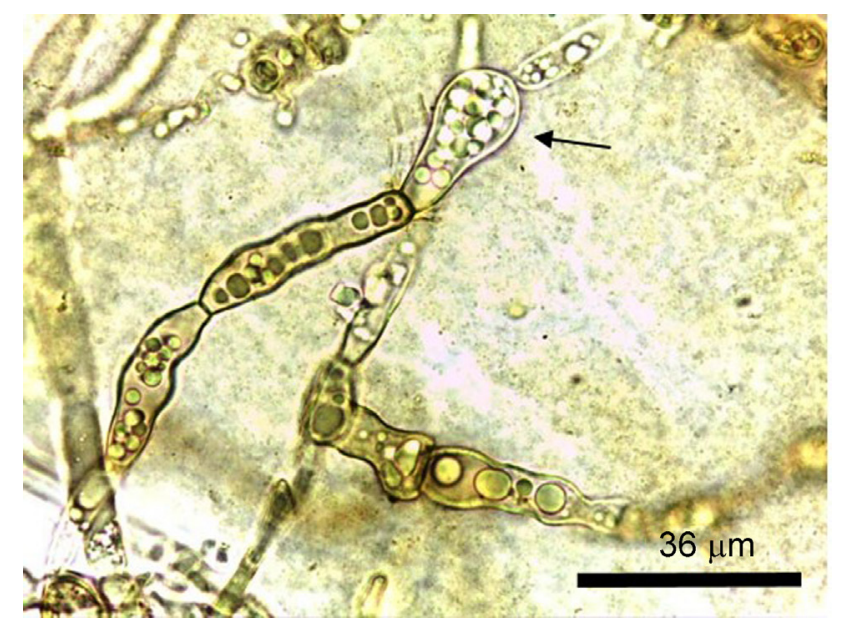

Fig. 1. Gametangium-like bodies produced from filamentous cells on Bristol medium (black arrow).

the other treatments (Table 2). Bristol medium provided $6.0 \mathrm{~cm}$ increase and, finally, HLE medium, $5.5 \mathrm{~cm}$. The mycelial growth in Petri dishes until day 4 better fitted a linear model for all culture media, where the models were significant $(P \leq 0.05)$ and had determination coefficient $\left(\mathrm{R}^{2}\right)$ above $98 \%$ (Table 2 ). The Trebouxia media enabled the obtaining of larger filamentous cells (length and width: $69.1 \times 6.1 \mu \mathrm{m}$ ) compared to other culture media (Table 3). Gametangium-like bodies were produced from filamentous cells on Bristol medium, without hormone addition (Fig. 1).

\section{Discussion}

Direct isolation from the injured tissue into agar media PDA, PSA, BBM, HLE, Bristol and Trebouxia was not successful. An explanation for this event may be attributed to the non-formation of filamentous cells, directly, from a foliar lesion in artificial agar culture media, since shaking was required to generate filamentous cells in vitro. That is, when subjected to shaking (120 rpm), detachment of sporangia from lesions into the liquid medium apparently allowed the subsequent development of filamentous cells. Other authors, such as Holcomb (1986) and Malagi et al. (2011), attempted algal isolation in PSA medium, and were unable to multiply it, suggesting that Cephaleuros sp. is a sensitive organism as to the isolation methodology and nutritional requirements.

Among the analyzed liquid media, Trebouxia was the one that allowed the algal isolation for later pricking into other culture media. This may be explained by the fact that the Trebouxia medium provides nitrogen through proteose peptone, which is an essential nutrient for algal growth (Ren et al., 2013). Likewise, Ponmurugan et al. (2010) also isolated the algae primarily in liquid medium for further pricking into agar medium. The PD and PS liquid media were not able to support growth of $C$. virescens and did not allow any growth in agaric media (PDA and PSA) when alga mycelium was picked from mycelium grown in the Trebouxia liquid media. Since PDA and PSA containing only sugar and starch as nutritional components, they are insufficient for in vitro Cephaleuros culture.

Algal cultivation in solid media BBM, HLE, Bristol and Trebouxia was only possible after isolation in Trebouxia liquid media. The following theories may explain this occurrence: (a) gradual adaptation of algae to artificial growth media, firstly liquid and then solid media, and (b) abundant growth of filamentous cells, which could facilitate the transfer of the microorganism to cultivation in solid media.

On GenBank platform (NBCI), 47 18S rRNA sequences of Cephaleuros genus were found, 23 of which are $C$. virescens species. In the present study, the sequences obtained from the DNA extracted directly from leaf lesions and from $\mathrm{H}-27-01$ showed $96 \%$ similarity with 13 sequences of C. virescens and less than $90 \%$ similarity with the species Trentepohlia and Phycopeltis, which belong in the same Cephaleuros monophyletic group (Boedeker et al., 2013; López-Bautista et al., 2006; Rindi et al., 2009; Suutari et al., 2010). In this context, the molecular findings contributed to the alga identification as $C$. virescens.

When grown on solid medium, the BBM and Trebouxia provided a higher growth rate than the others, because they are the most complete media among those evaluated, providing essential nutrients (phosphorus, calcium, magnesium, boron, copper and zinc) for the microalgae development (Ponmurugan et al., 2010). In a recent study, Ponmurugan et al. (2010) tested several culture media, synthetic and natural, for in vitro $C$. parasiticus growth and similarly achieved outstanding growth in Trebouxia media. Fast my- 
celial growth is important, since it reduces the contaminant levels during the process of obtaining pure microorganism culture (Sales-Campos and Andrade, 2010).

Interestingly, in addition to promoting higher colony growth rates, the Trebouxia medium enabled larger lengths and widths for $C$. virescens filamentous cells, suggesting that these events are directly related. Moreover, such data are valuable to the Phycology field, since culturing characteristics (mycelial development and its cell morphology) in agar media are considered useful for Cephaleuros species identification (Suto and Ohtani, 2011).

There are few studies related to the use of hormones to induce growth and reproduction of algae. Chowdary (1969) reported that gametangia and sporangia were produced in $C$. virescens when auxins (indole-3-acetic acid, butyric indole acid and indole-propionic acid) were added to the culture media. In an opposite way, the hormone addition had made no difference in the Bristol and Trebouxia media.

In accordance with Suto and Ohtani (2011), an important observation was the formation of structures like gametangia formed from filamentous cells (Fig. 1), highlighting the importance to mention that when under artificial culture, the colony characteristics are quite different from those observed when the algae develop in living leaves (Jose and Chowdary, 1977; Suto and Ohtani, 2009).

Finally, the conclusions of this study were: (1) molecular characterization indicated that the algae found in mango tree is Cephaleuros virescens; (2) C. virescens must be isolated primarily in liquid medium for further pricking into agar medium; (3) The highest mycelial growth average in Petri dishes occurred when the algae were grown in Trebouxia and BBM; (4) Trebouxia enabled larger cells in the filamentous cells when compared to other culture media.

\section{Acknowledgments}

The authors thank the National Council for Scientific and Technological Development (CNPq) for a scientific initiation scholarship, the Foundation for Support to Goiás State Research (FAPEG) for the master's program scholarship and financial assistance in the paper preparation (AUXPE 2370/2014), the Coordination for the Improvement of Higher Education (CAPES) for two Post-doctorate scholarships, and the Scholarship Program for Incentive to Scientific Research and Production (PROBIP) of Goiás State University (UEG) for the scholarship in research production.

\section{References}

Agrios, G. N. 2005. Plant pathology. 5th ed. Elsevier Academic
Press, Amsterdam, The Netherlands.

Boedeker, C., Karsten, U., Leliaert, F. and Zuccarello, G. C. 2013. Molecular, biochemical and morphological data suggest an affiliation of Spongiochrysis hawaiiensis with the Trentepohliales (Ulvophyceae, Chlorophyta). Phycol. Res. 61:133-144.

Chowdary, Y. B. K. 1969. Induction of reproductive organs in Cephaleuros virescens. Indian J. Microbiol. 3:153-158.

Ferreira, D. F. 2011. Sisvar: a computer statistical analysis system. Cienc. Agrotec. 35:1039-1042.

Hamby, R. K., Sims, L., Issel, L. and Zimmer, E. 1988. Direct ribosomal RNA sequencing: optimization of extraction and sequencing methods for work with higher plants. Plant Mol. Biol. Rep. 6:175-192.

Han, K., Park, M., Park, J. and Shin, H. 2011. First report of algal leaf spot associated with Cephaleuros virescens on greenhouse grown Ficus benghalensis in Korea. Australas Plant Dis. Notes 6:72-73.

Holcomb, G. E. 1986. Hosts of the parasitic alga Cephaleuros virescens in Louisiana and new host records for the continental United States. Plant. Dis. 70:1080-1083.

Jose, G. and Chowdary, Y. B. K. 1977. Karyological studies on Cephaleuros Kunze. Acta Bot. Indica 5:114-122.

Leliaert, F., Smith, D. R., Moreau, H., Herron, M. D., Verbruggen, H., Delwiche, C. F. and Clerck, O. 2012. Phylogeny and molecular evolution of the green algae. Crit. Rev. Plant Sci. 31:1-46.

López-Bautista, J. M., Rindi, F. and Guiry, M. D. 2006. Molecular systematics of the subaerial green algal order Trentepohliales: an assessment based on morphological and molecular data. Int. J. Syst. Evol. Microbiol. 56:1709-1715.

Malagi, G., Santos, I., Mazaro, S. M. and Guginski, C. A. 2011. Detecção de mancha-de-alga (Cephaleuros virescens Kunze) em citros no estado do Paraná. Revista Brasileira de Agrociência 17:148-152.

Nelson, S. C. 2008. Cephaleuros species, the plant-parasitic green algae. University of Hawaii, Honolulu, HI. 6 pp.

Ponmurugan, P., Baby, U. I. and Rajkumar, R. 2007. Growth, photosynthetic and biochemical responses of tea cultivars infected with various diseases. Photosynthetica 45:143-146.

Ponmurugan, P., Saravanan, D. and Ramya, M. 2010. Culture and biochemical analysis of a tea algal pathogen, Cephaleuros parasiticus. J. Phycol. 46:1017-1023.

Ponmurugan, P., Saravanan, D., Ramya, M., Srinivasan, T. R., Baby, U. U. and Ajay, D. 2009. Studies on Cephaleuros parasiticus Karst, a pathogenic alga causing red rust disease in tea plantations. J. Plant. Crops 37:70-73.

Ren, H., Liu, B., Ma, C., Zhao, L. and Ren, N. 2013. A new lipidrich microalga Scenedesmus sp. strain R-16 isolated using Nile red staining: effects of carbon and nitrogen sources and initial $\mathrm{pH}$ on the biomass and lipid production. Biotechnol. Biofuels 6:143.

Rindi, F., Lam, D. W. and López-Bautista, J. M. 2009. Phylogenetic relationship and species circumcription in Trentepohlia and Printzina (Trentepohliales, Chlorophyta). Mol. Phylo- 
genet. Evol. 52:329-339.

Sales-Campos, C. and Andrade, M. C. N. 2010. Most favorable temperature and culture medium for the mycelial growth of a strain of Lentinus strigosus from the Amazon region. Arq. Inst. Biol. 77:539-543.

Suto, Y. and Ohtani, S. 2009. Morphology and taxonomy of five Cephaleuros species (Trentepohliaceae, Chlorophyta) from Japan, including three new species. Phycologia 48:213-236.

Suto, Y. and Ohtani, S. 2011. Morphological features and chro- mosome numbers in cultures of five Cephaleuros species (Trentepohliaceae, Chlorophyta) from Japan. Phycol. Res. 59:42-51.

Suutari, M., Majaneva, M., Fewer, D. P., Voirin, B., Aiello, A., Friedl, T., Chiarello, A. G. and Blomster, J. 2010. Molecular evidence for a diverse green algal community growing in the hair of sloths and a specific association with Trichophilus welckeri (Chlorophyta, Ulvophyceae). BMC Evol. Biol. 10:86-97. 